\title{
Adsorption of malachite green by polyaniline-nickel ferrite magnetic nanocomposite: an isotherm and kinetic study
}

\author{
Manohar R. Patil • V. S. Shrivastava
}

Received: 7 September 2014 / Accepted: 15 November 2014/Published online: 30 November 2014

(C) The Author(s) 2014. This article is published with open access at Springerlink.com

\begin{abstract}
This work deals with the development of an efficient method for the removal of a MG (malachite green) dye from aqueous solution using polyaniline (PANI)Nickel ferrite $\left(\mathrm{NiFe}_{2} \mathrm{O}_{4}\right)$ magnetic nanocomposite. It is successfully synthesised in situ through self polymerisation of monomer aniline. Adsorptive removal studies are carried out for water soluble MG dye using PANI-Nickel ferrite magnetic nanocomposite in aqueous solution. Different parameters like dose of adsorbent, contact time, different initial conc., and $\mathrm{pH}$ have been studied to optimise reaction condition. It is concluded that adsorptive removal by PANI-Nickel ferrite magnetic nanocomposite is an efficient method for removing a MG dye from aqueous solution than work done before. The optimum conditions for the removal of the dye are initial concentration $30 \mathrm{mg} \mathrm{l}^{-1}$, adsorbent dose $5 \mathrm{gm}^{-1}$ and $\mathrm{pH} 7$. The adsorption capacity is found $4.09 \mathrm{mg} \mathrm{g}^{-1}$ at optimum condition $30 \mathrm{mg} \mathrm{l}^{-1}$. The adsorption followed pseudo-second-order kinetics. The experimental isotherm is found to fit with Langmuir equation. The prepared adsorbent is characterised by techniques SEM, EDS, XRD and VSM.
\end{abstract}

Keywords Adsorptive removal · MG dye · PANI$\mathrm{NiFe}_{2} \mathrm{O}_{4} \cdot$ Magnetic nanocomposite $\cdot$ SEM $\cdot$ XRD

\footnotetext{
M. R. Patil · V. S. Shrivastava $(\square)$

Nano-Chemistry Research Laboratory, G.T.P. College, Nandurbar 425412, India

e-mail: drvinod_shrivastava@yahoo.com

M. R. Patil

e-mail: profmanoharpatil@gmail.com
}

\section{Introduction}

Water pollution by dyes has been a worldwide problem. Colour is the first contaminant to be recognised in wastewater. Dyes are used in different industries such as paper, plastics, food cosmetics, leather, pharmaceutical dyestuffs textiles etc. to colour the product. As a result considerable amount of colour water is generated (Ezgi et al. 2008). Even small quantities of dyes can colour huge water bodies, which influences aesthetic merit and decreases light penetration needed for photosynthesis. Furthermore many dyes are toxic or carcinogenic (Akl et al. 2013). The cationic dye like Malachite green caused carcinogenic symptoms. Culp (2002). A wide range of method has been developed for the removal of synthetic dyes from water and wastewater to decrease their impact on environment. Adsorption is very known method in the world. Adsorption using low-cost adsorbents is an effective and affordable method for water purification. The process of adsorption has an edge over the other method due to its sludge free clean operation and completely removed dyes even from the diluted solution (Azhar et al. 2005).

Adsorption using low-cost adsorbents is an effective and affordable method for water purification. Many attempts have been made by researchers for dye removal using various non-conventional adsorbent materials. (Tavallali and Daneshyar 2012; God bole and Sawant 2006; Hammed and Ahmed 2009). Now a days polyaniline (PANI) has attracted much attention because of its unique properties and advantages. It has easy way to prepare due to good environmental stability. It exists in various oxidation states. So PANI is frequently used for the removal of dyes from contaminated wastewater. Polyaniline-functionalised magnetic nanoparticles has been used for the removal of toxic dye from wastewater (Mahto et al. 2014). 
The present investigation report is a new, simple and fast method for removal and recovery of a MG dye using PANI- $\mathrm{NiFe}_{2} \mathrm{O}_{4}$ magnetic nanocomposite as an adsorbent. The main objective of the present work is to solve the problem of dyes industry wastewater pollution.

\section{Experimental}

Materials and methods

The structure of Malachite green (as shown in Fig. 1), $\mathrm{NiCl}_{2}, \mathrm{FeCl}_{3} \cdot 6 \mathrm{H}_{2} \mathrm{O}$, monomer aniline, Distilled water, Ammonium per-sulphate $\left(\mathrm{NH}_{4}\right)_{2} \mathrm{~S}_{2} \mathrm{O}_{8}$. The water soluble MG dye which has M.F. $\mathrm{C}_{23} \mathrm{H}_{25} \mathrm{~N}_{2} \mathrm{Cl}$, M.W. $364.91 \mathrm{~g} \mathrm{~mole}^{-1}$, M.P. $112{ }^{\circ} \mathrm{C}$ and PANI-NiFe $\mathrm{O}_{4}$ is used as an adsorbent. All chemicals and reagents were of analytical grade purity. The structure of dye is presented in Fig. 1. The stock solution $1,000 \mathrm{mg}^{-1}$. of dye was prepared in double distilled water. In $50 \mathrm{ml}$ of dye solution of the desired concentration, of a different adsorbent dose is

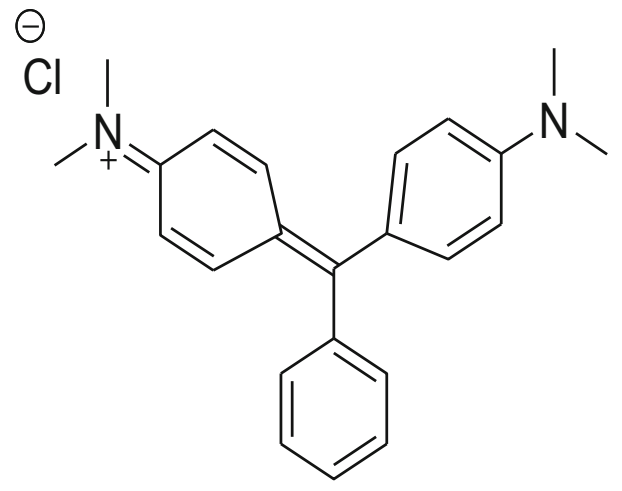

Fig. 1 Structure of Malachite Green
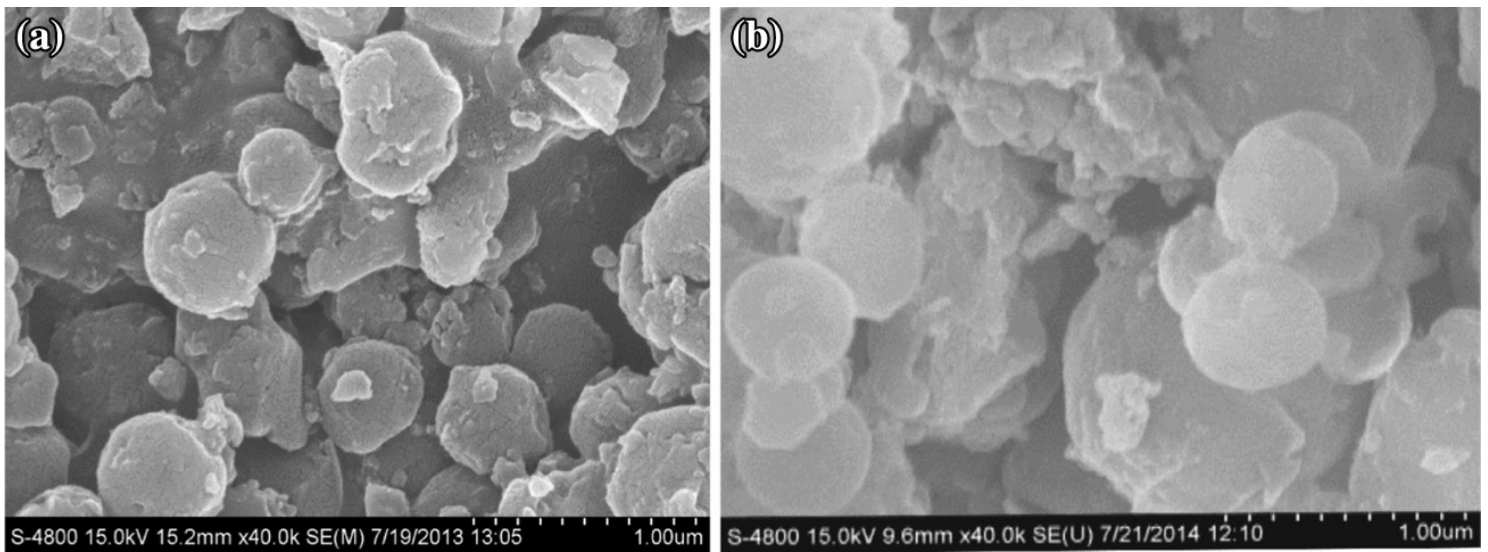

Fig. 2 a SEM images of prepared PANI-NiFe ${ }_{2} \mathrm{O}_{4}$ nanocomposite before adsorption. b SEM image of PANI-NiFe $\mathrm{O}_{4}$ nanocomposite after adsorption of dye

$\mathrm{NiFe}_{2} \mathrm{O}_{4}$ nanoparticles were synthesized according to the following procedures: $1.0 \mathrm{~g}$ of Nickel chloride $\left(\mathrm{NiCl}_{2} \cdot 6 \mathrm{H}_{2} \mathrm{O}\right)(5 \mathrm{mmol})$ in $5 \mathrm{ml}$ of deionised water and $1.63 \mathrm{~g}$ of ferric chloride $\left(\mathrm{FeCl}_{3} \cdot 6 \mathrm{H}_{2} \mathrm{O}\right)(6 \mathrm{mmol})$ in $5 \mathrm{ml}$ of deionised water were mixed at room temperature. The above mixture was dropped into $200 \mathrm{ml}$ aqueous ammonia solution $(0.6 \mathrm{M})$ in $20 \mathrm{~min}$ with vigorous stirring. The $\mathrm{pH}$ values of the reaction mixture were kept in the range of 11-12 with the addition of a concentrated ammonium hydroxide solution. The resulting nanoparticles were separated by centrifugation at 2,800 rpm for $10 \mathrm{~min}$, and then these nanoparticles were calcinated in muffle furnace for $4 \mathrm{~h}$ at $400{ }^{\circ} \mathrm{C}$.

\section{Synthesis of $\mathrm{PANI}-\mathrm{NiFe}_{2} \mathrm{O}_{4}$ nanocomposite}

PANI-NiFe ${ }_{2} \mathrm{O}_{4}$ nanocomposite was synthesized via selfassembly method using ammonium persulfate APS is used as an oxidant without the addition of organic dopants or surfactants. During the synthesis process, it is as followed: $0.64 \mathrm{~mol}^{-1}$ aniline monomer into polymerization vessel containing $1 \mathrm{~g}$. $\mathrm{NiFe}_{2} \mathrm{O}_{4}$ in $100 \mathrm{ml}$ of $1.14 \mathrm{~mol} \mathrm{l}^{-1} \mathrm{H}_{2} \mathrm{SO}_{4}$ acid solution at room temperature and magnetic stirring for $8 \mathrm{~h}$. Then $50 \mathrm{ml}(1 \mathrm{M})$ of ammonium per-sulphate $\left(\mathrm{NH}_{4}\right)_{2} \mathrm{~S}_{2} \mathrm{O}_{8}$ was added to the above mixture reaction.

added and stirred with magnetic stirrer. At specific time
interval suitable aliquot of the sample is withdrawn and analysed after centrifugation. The changes of dye concentration are determined by UV-visible double beam spectrophotometer (systronics model-2203) at $\lambda \max 618 \mathrm{~nm}$ in our laboratory.

\section{Preparation of PANI-NiFe ${ }_{2} \mathrm{O}_{4}$ nanocomposite}

\section{Synthesis of $\mathrm{NiFe}_{2} \mathrm{O}_{4}$ nanoparticles}




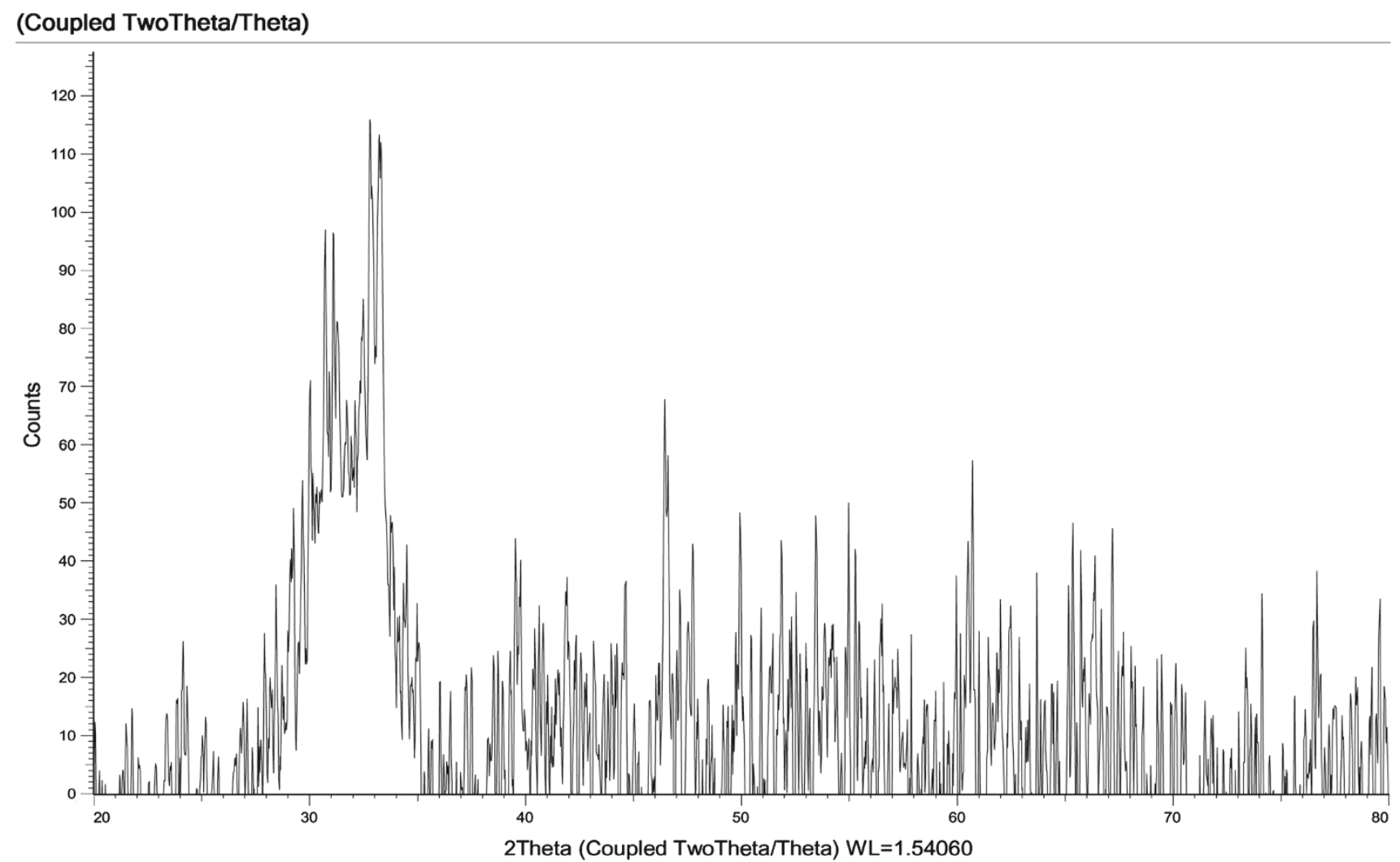

\begin{tabular}{|c|l|}
\hline Diffraction angle $(2 \theta)$ in Degree & Plane $(\mathrm{h}, \mathrm{k}, \mathrm{l})$ \\
\hline $30.290^{0}$ & $2,2,0$ \\
\hline $37.323^{0}$ & $2,2,2$ \\
\hline $66.250^{0}$ & $5,3,1$ \\
\hline $71.493^{0}$ & $6,2,0$ \\
\hline $74.560^{0}$ & $5,3,3$ \\
\hline $75.572^{0}$ & $6,2,2$ \\
\hline
\end{tabular}

Fig. 3 XRD image of prepared PANI-NiFe ${ }_{2} \mathrm{O}_{4}$ nanocomposite

Resulting precipitate was collected by filtration then washed with deionised water and methanol three times, respectively. The product was dried in oven at $70{ }^{\circ} \mathrm{C}$ for 24 $\mathrm{H}$ to obtain black-green powder of PANI- $\mathrm{NiFe}_{2} \mathrm{O}_{4}$ nanocomposite (Patil and Shrivastava 2014).

\section{Results and discussion}

SEM analysis

The PANI-NiFe ${ }_{2} \mathrm{O}_{4}$ nanocomposites are analysed by SEM before and after adsorption of Malachite green dye is shown in the Fig. 2a, b, respectively. It show SEM micrographs of PANI-NiFe $\mathrm{O}_{4}$. Figure. 2a shows surface texture, colour and porosity on $\mathrm{PANI}-\mathrm{NiFe}_{2} \mathrm{O}_{4}$. It has homogeneous surface, microspores and mesopores as seen from its surface micrographs. It is black-green in colour, Fig. 2b shows adsorption of MG dye on PANI-NiFe ${ }_{2} \mathrm{O}_{4}$ surface. The cluster of a MG dye is shown on the surface of adsorbent. The MG dye is adsorbed in microspores and mesopores of adsorbent PANI-NiFe ${ }_{2} \mathrm{O}_{4}$ Fig. 2b.

XRD analysis

The XRD diagram of PANI- $\mathrm{NiFe}_{2} \mathrm{O}_{4}$ is as shown in Fig. 3 .It shows main peak at $30.290^{\circ}$ and subsidiary peak at $37.323^{\circ}, 66.250^{\circ}$. It shows match scan with JCPDS-PDF 
NO-00-044-1485 at radiation of $1.54 \mathrm{~A}^{\circ}$. The high intensity of peaks indicates the highly crystalline nature of PANI$\mathrm{NiFe}_{2} \mathrm{O}_{4}$. The average particle size of PANI- $\mathrm{NiFe}_{2} \mathrm{O}_{4}$ is estimated by Scherrer formula is $28 \mathrm{~nm}$.

Electron dispersive X-Ray spectroscopy (EDS) analysis

EDS can be used to find the chemical composition of materials down to a spot size of a few microns, and to create element composition maps over a much broader raster area. Together, these capabilities provide fundamental compositional information for a wide variety of materials. From the analysis it is known that PANI$\mathrm{NiFe}_{2} \mathrm{O}_{4}$. nanocomposite consists of exact elemental composition of specific element like $\mathrm{Ni}-1.55 \%, \mathrm{Fe}-$ $2.15 \%, \mathrm{~N}-15.63 \%, \mathrm{O}-22.02 \%, \mathrm{C}-57.19 \%$ etc. as shown in the (Fig. 4). As PANI-NiFe ${ }_{2} \mathrm{O}_{4}$ is conducting material therefore it needs to coat with gold $(\mathrm{Au})$ metal.

VSM analysis

Vibrating sample magnetometer (VSM) is widely used for study of magnetic nature of adsorbent. The magnetic property of PANI- $\mathrm{NiFe}_{2} \mathrm{O} 4$ and $\mathrm{NiFe}_{2} \mathrm{O}_{4}$ was analysed at R.T by VSM (Vibrating sample magnetometer) at applied field of 20,000 gauss. The $\mathrm{NiFe}_{2} \mathrm{O}_{4}$ nanoparticles show the value of saturation magnetisation is $4.6 \mathrm{emu} \mathrm{g}^{-1}$. It is shown in the curve (a) of the Fig. 5. The PANI-NiFe $2 \mathrm{O}_{4}$ nanocomposite the value of saturation magnetisation (Ms) is $3.7 \mathrm{emu} \mathrm{g}^{-1}$, which is lower than $\mathrm{NiFe}_{2} \mathrm{O}_{4}$. It is shown in the curve (b) of the Fig. 5. So this magnetisation curve of the sample shows a weak ferromagnetic behaviour, with
Fig. 4 EDS image of prepared gold $(\mathrm{Au})$ coated PANI$\mathrm{NiFe}_{2} \mathrm{O}_{4}$ nanocomposite

Fig. 5 VSM analysis of prepared $\mathrm{PANI}-\mathrm{NiFe}_{2} \mathrm{O}_{4}$ nanocomposite
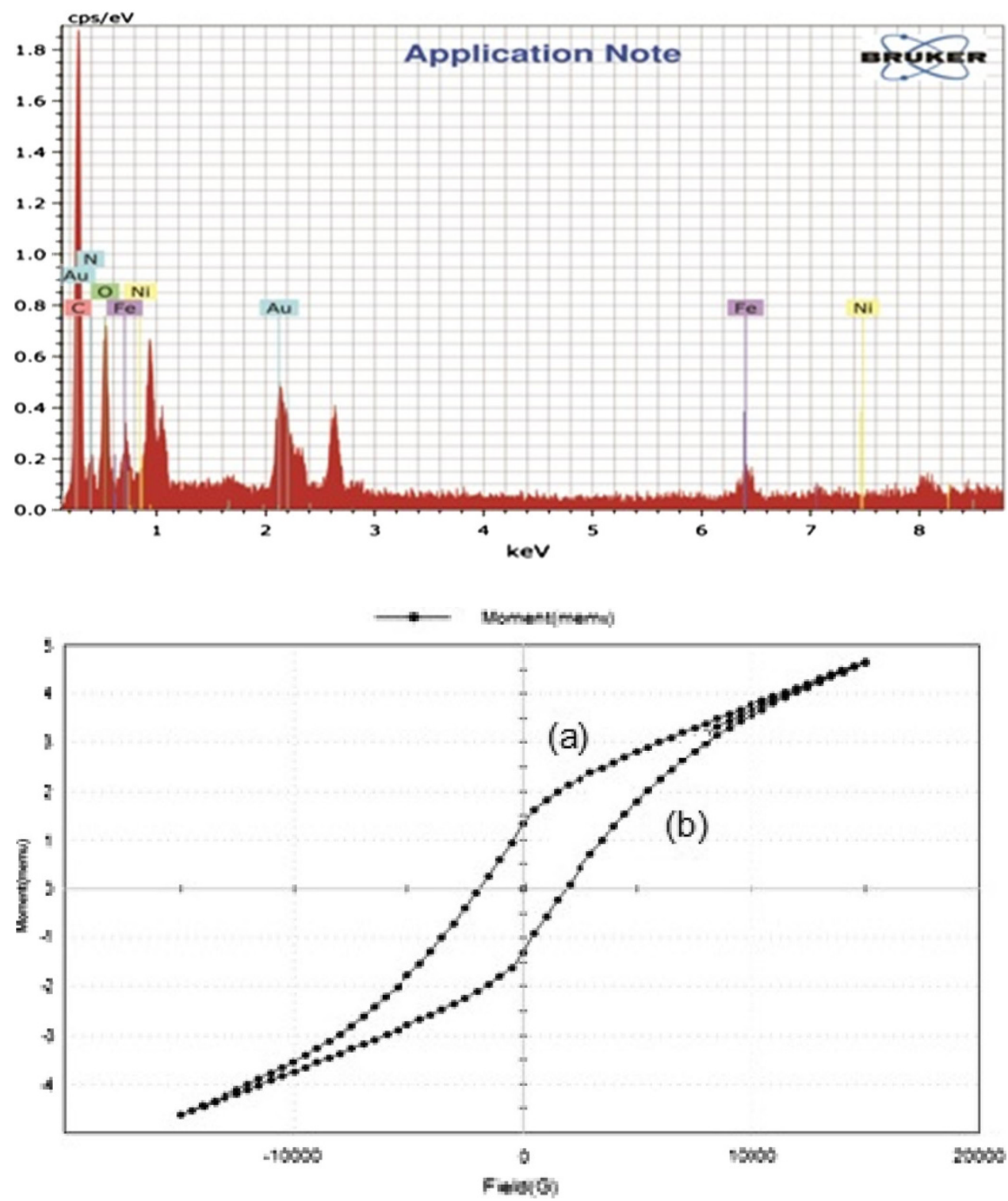


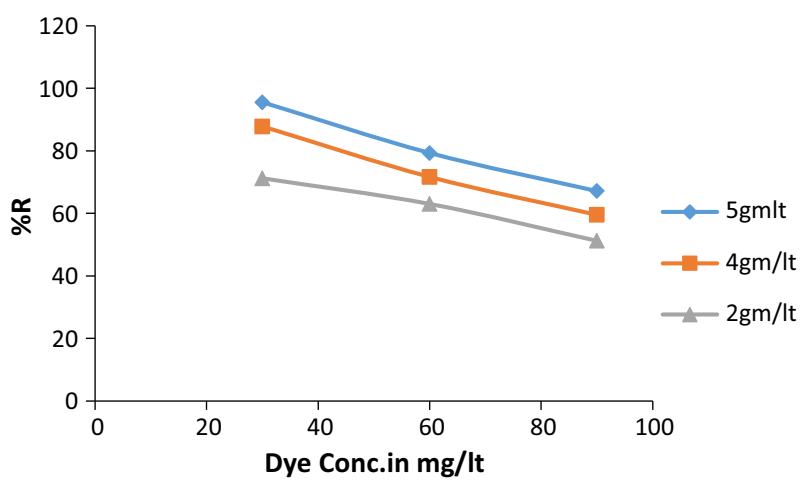

Fig. 6 Effect of adsorbent dose on \% removal of a MG dye for different initial dye conc. With contact time $240 \mathrm{~min}, \mathrm{pH} 7$

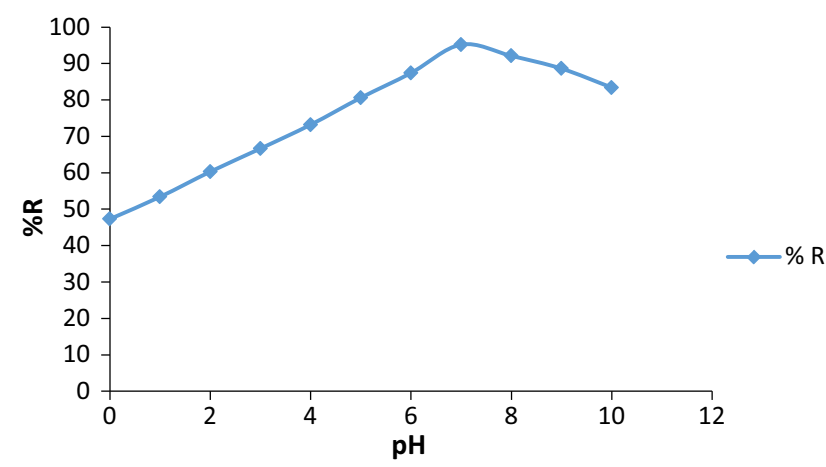

Fig. 7 Effect of $\mathrm{pH}$ on \% removal of a MG dye by PANI-NiFe ${ }_{2} \mathrm{O}_{4}$ adsorbent dose $5 \mathrm{~g} \mathrm{l}^{-1}$ at $30 \mathrm{mg}^{-1}$

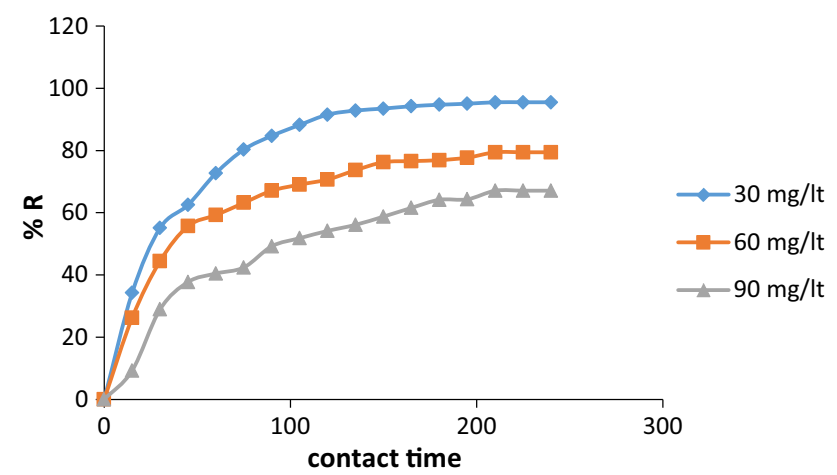

Fig. 8 Effect of contact time and initial concentration of a MG dye on $\%$ removal at adsorbent dose $5 \mathrm{~g}^{-1}$ at $\mathrm{pH} 7$

hysteresis. The magnetic property of nanocomposite is dependent on the sample shape, crystallinity; therefore it can be adjusted to obtain optimum property.

\section{Parametric studies}

The adsorptive removal of MG is studied at $\lambda \max 618 \mathrm{~nm}$. The optimum condition for removal of dyes is $30 \mathrm{mg}^{-1}$.

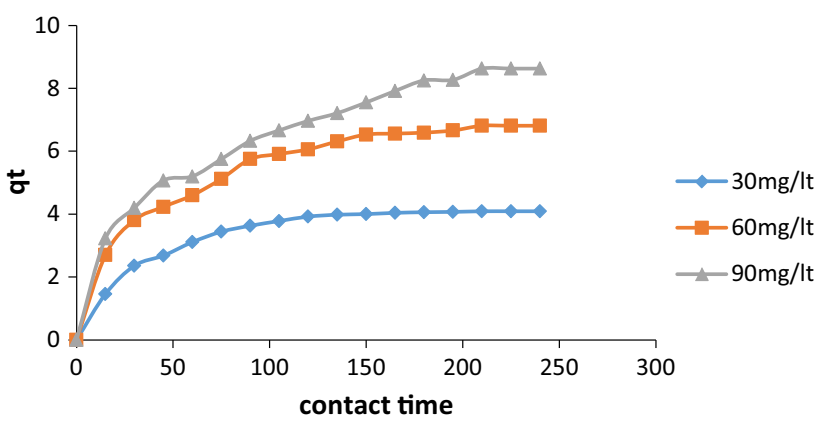

Fig. 9 Amount of a MG dye adsorbed $q_{\mathrm{t}}\left(\mathrm{mg} \mathrm{g}^{-1}\right)$ with time for different initial dye concentration: $\mathrm{pH} 7$, adsorbent dose $5 \mathrm{gm}^{-1}$

$\mathrm{pH} 7$, PANI-NiFe $\mathrm{O}_{4}, 5 \mathrm{gm} \mathrm{l}^{-1}$. The results obtained during this study are as shown in the Figs. $(6,7,8,9)$.

Effect of adsorbent dose

The effect of adsorbent dose on the removal of MG dye is studied. The percentage removal of a MG dye by PANI$\mathrm{NiFe}_{2} \mathrm{O}_{4}$ nanocomposite at different adsorbent doses $2-5 \mathrm{gm} \mathrm{l}^{-1}$ for $30-90 \mathrm{mg} \mathrm{l}^{-1}$ of dye conc. is studied as shown in the (Fig. 6). Adsorptive removal of MG increases rapidly from 71.2 to $95.3 \%$ with an increasing amount from 2 to $5 \mathrm{gm} \mathrm{l}^{-1}$ of PANI-NiFe ${ }_{2} \mathrm{O}_{4}$ nanocomposite. As the number of active sites for the adsorption increases, removal of MG also increases is as shown in the (Fig. 6). It is also observed that, as the conc. of dye increases from 30 to $90 \mathrm{mg} \mathrm{l}^{-1}$. \% removal of dye decreases from 95.2 to $67.1 \%$ for adsorbent dose $5 \mathrm{gm} \mathrm{l}^{-1}$.

\section{Effect of $\mathrm{pH}$}

The role of $\mathrm{pH}$ on the adsorptive removal of MG is studied in the $\mathrm{pH}$ range $0-10$ at dye concentration $30 \mathrm{mg} \mathrm{l}^{-1}$ and PANI- $\mathrm{NiFe}_{2} \mathrm{O}_{4}$ concentration $5 \mathrm{gm} \mathrm{l}^{-1}$. It is observed that the rate of adsorption increases with an increase in $\mathrm{pH}$ up to 7 is as shown in the (Fig. 7). As the $\mathrm{pH}$ increases up to 7 ,

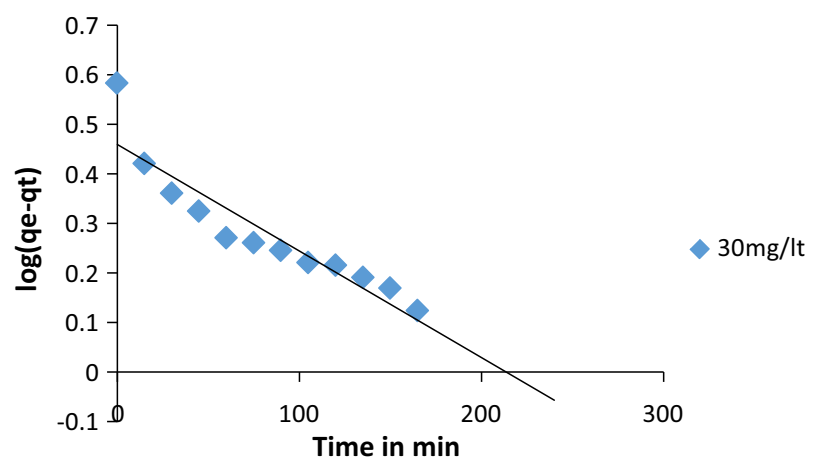

Fig. 10 pseudo-first-order kinetics plots for the removal of a MG at different initial dye concentration: adsorbent dose $5 \mathrm{gm} \mathrm{l}^{-1}, \mathrm{pH} 7$

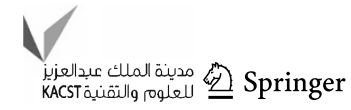


MG cation adsorbed on surface of $\mathrm{PANI} / \mathrm{NiFe}_{2} \mathrm{O}_{4}$. At $\mathrm{pH} 7$ maximum adsorption takes place because PANI amine group has easily available lone pair for the formation of bond with MG dye. At low $\mathrm{pH}$ cationic dye becomes more acidic in nature therefore adsorption efficiency is low. When the $\mathrm{pH}$ increases 7 onwards, the MG dye becomes anionic, so dye molecule is repelled by lone pair electron of PANI-NiFe ${ }_{2} \mathrm{O}_{4}$, therefore surface would result in reduction in efficiency of adsorption of MG dye.

\section{Effect of contact time}

The effect of contact time and initial dye concentration on percentage removal of MG dye is shown in Figs. 6 and 8. It is studied that the rate of dye removal is faster in first $60 \mathrm{~min}$ after that decreases gradually, then it attains equilibrium at $210 \mathrm{~min}$ and after that it remains constant. The percent removal at equilibrium decreases from 95.53 to $67.1 \%$ as dye concentration is increased from 30 to $90 \mathrm{mg} \mathrm{l}^{-1}$ for $5 \mathrm{gm} \mathrm{l}^{-1}$ adsorbent dose. The amount of dye adsorbed $\mathrm{qt}\left(\mathrm{mg} \mathrm{g}^{-1}\right.$ ) increases from 4.09 to $8.62 \mathrm{mg} \mathrm{g}^{-1}$ for dye conc. $30 \mathrm{mg} \mathrm{l}^{-1}$ to $90 \mathrm{mg} \mathrm{l}^{-1}$ as shown in Fig. 9.

\section{Adsorption kinetics study}

The adsorption kinetics gives the idea about mechanism of adsorption, from which efficiency of process estimated.

Table 1 comparison of the pseudo-first-order and pseudo-secondorder adsorption rate constants and calculated and experimental $\mathrm{q}_{\mathrm{e}}$ values for different initial concentrations

\begin{tabular}{|c|c|c|c|c|c|}
\hline $\begin{array}{l}\text { Adsorbent } \\
\text { dose }\left(\mathrm{g} \mathrm{l}^{-1}\right)\end{array}$ & 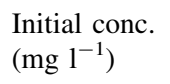 & $\begin{array}{l}Q_{\mathrm{e}}(\exp ) \\
\left(\mathrm{mg} \mathrm{g}^{-1}\right)\end{array}$ & $\begin{array}{l}Q_{\mathrm{e}}(\mathrm{cal}) \\
\left(\mathrm{mg} \mathrm{g}^{-1}\right)\end{array}$ & $\begin{array}{l}K_{1} \\
\left(\min ^{-1}\right)\end{array}$ & $R^{2}$ \\
\hline \multicolumn{6}{|l|}{$\begin{array}{l}\text { Pseudo-first } \\
\text { order }\end{array}$} \\
\hline \multirow[t]{3}{*}{5} & 30 & 4.09 & 2.87 & 0.0048 & 0.8527 \\
\hline & 60 & 6.81 & 3.61 & 0.0076 & 0.8125 \\
\hline & 90 & 8.62 & 7.14 & 0.011 & 0.9773 \\
\hline \multirow[t]{3}{*}{2} & 30 & 2.3 & 1.65 & 0.002 & 0.867 \\
\hline & 60 & 3.34 & 1.45 & 0.004 & 0.853 \\
\hline & 90 & 4.2 & 1.56 & 0.009 & 0.965 \\
\hline $\begin{array}{l}\text { Adsorbent } \\
\text { dose }\end{array}$ & $\begin{array}{l}\text { Initial co } \\
\left(\mathrm{mg} \mathrm{l}^{-1}\right)\end{array}$ & $\begin{array}{l}\text { pnc. } Q_{\mathrm{e}}(\exp ) \\
\left(\mathrm{mg} \mathrm{g}^{-1}\right.\end{array}$ & ${ }_{-1}^{)} \underset{\left(\mathrm{mg} \mathrm{g}^{-1}\right.}{Q_{\mathrm{e}}(\mathrm{cal})}$ & $\begin{array}{l}K_{2} \\
\left.1 \min ^{-1}\right)\end{array}$ & $R^{2}$ \\
\hline \multicolumn{6}{|c|}{ Pseudo-second order } \\
\hline \multirow[t]{3}{*}{5} & 30 & 4.09 & 4.67 & 0.0075 & 0.9975 \\
\hline & 60 & 6.81 & 7.593 & 0.0048 & 0.9982 \\
\hline & 90 & 8.62 & 10.95 & 0.0014 & 0.9938 \\
\hline \multirow[t]{3}{*}{2} & 30 & 2.3 & 1.43 & 0.001 & 0.997 \\
\hline & 60 & 3.34 & 0.96 & 0.003 & 0.998 \\
\hline & 90 & 4.2 & 0.97 & 0.01 & 0.997 \\
\hline
\end{tabular}

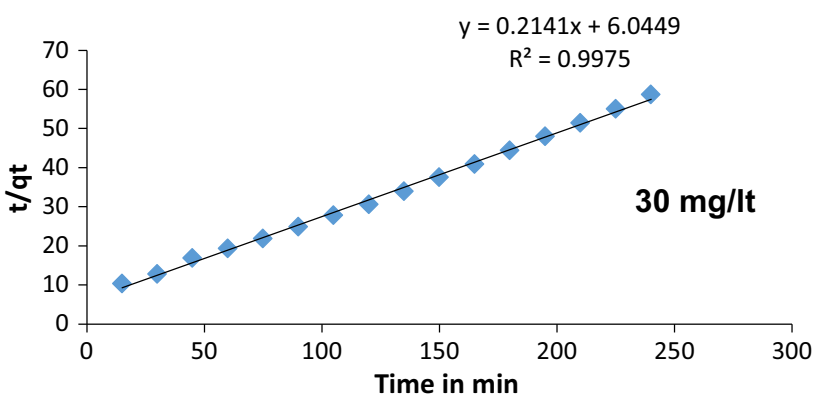

Fig. 11 pseudo-second-order kinetics plots for the removal of a MG at different initial dye concentration: adsorbent dose $5 \mathrm{gm}^{-1}, \mathrm{pH} 7$

Pseudo-first order

The integrated form of equation is

$\log \left(q_{\mathrm{e}}-q_{\mathrm{t}}\right)=\log q_{\mathrm{e}}-\left(\frac{k_{1}}{2.303}\right) t$

where $q_{\mathrm{e}}$ and $q_{\mathrm{t}}$ are the amounts of dye adsorbed $\left(\mathrm{mg} \mathrm{g}^{-1}\right)$ on PANI- $\mathrm{NiFe}_{2} \mathrm{O}_{4}$ at equilibrium and at time $t$ (min) respectively, while $K_{1}$ is the rate constant calculated from the slope of the plot log $\left(q_{\mathrm{e}}-q_{\mathrm{t}}\right)$ Vs time is as shown in (Fig. 10). The linear relationship of the plot for $30,60,90 \mathrm{mg} \mathrm{l}^{-1}$.dye concentration indicates invalidity of equation. These calculated $K_{1}$ and correlation coefficient $r^{2}$ values are shown in Table 1. The correlation coefficient $r^{2}$ for the plots are not in linearity, the calculated $q_{\mathrm{e}}$ values from first-order kinetics plots are very small as compared to experimental $q_{\mathrm{e}}$ values (as shown in Table 1). This shows that the pseudo-first-order kinetic model is not applicable to predict the adsorption kinetics of a $\mathrm{MG}$ dye on PANI-NiFe ${ }_{2} \mathrm{O}_{4}$ nanocomposite.

Pseudo-second order

Adsorption kinetics is explained by second order model is represented by equation.

$\frac{t}{q_{\mathrm{t}}}=\frac{1}{k_{2} q_{\mathrm{e}} 2}+\frac{t}{q_{\mathrm{e}}}$

where $K_{2}$ is rate constant for second order adsorption ( $\mathrm{g} \mathrm{mg}^{-1} \min ^{-1}$ ), while $k_{2}$ and $q_{\mathrm{e}}$ are determined from slope

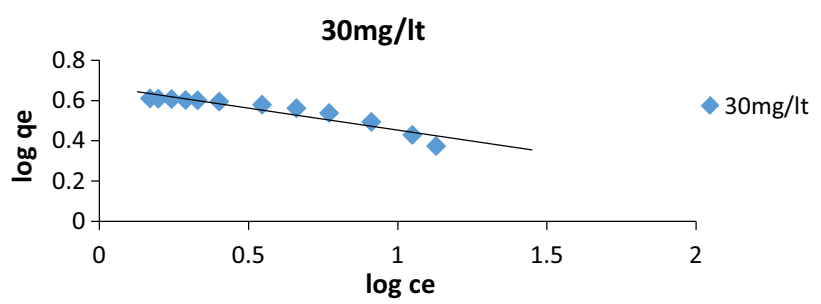

Fig. 12 Freundlich plot for adsorption of a MG dye by PANI$\mathrm{NiFe}_{2} \mathrm{O}_{4}$ 
Table 2 Freundlich and Langmuir coefficients for adsorption of a MG dye on PANI- $\mathrm{NiFe}_{2} \mathrm{O}_{4}$ for different dye concentration at $\mathrm{pH} 7$

\begin{tabular}{|c|c|c|c|c|c|c|c|c|c|}
\hline \multirow[t]{2}{*}{ Adsorbent dose $\left(\mathrm{mg} \mathrm{l}^{-1}\right)$} & \multicolumn{3}{|l|}{ Freundlich coefficients } & \multirow[b]{2}{*}{$1 / n$} & \multirow[b]{2}{*}{$R^{2}$} & \multirow[b]{2}{*}{$Q_{0}\left(\mathrm{mg} \mathrm{g}^{-1}\right)$} & \multicolumn{3}{|c|}{ Langmuir coefficients } \\
\hline & Dye conc. $\left(\mathrm{mg} \mathrm{l}^{-1}\right)$ & $K_{\mathrm{f}}\left(\mathrm{lg}^{-1}\right)$ & $N$ & & & & $B$ & RL & $R^{2}$ \\
\hline \multirow[t]{3}{*}{2} & 30 & 2.229 & 4.28 & 0.23 & 0.881 & 1.17 & 0.08 & 0.033 & 0.997 \\
\hline & 60 & 7.436 & 2.57 & 0.389 & 0.946 & 3.42 & 0.61 & 0.025 & 0.991 \\
\hline & 90 & 42.86 & 2.03 & 0.492 & 0.8937 & 2.31 & 0.02 & 0.084 & 0.9871 \\
\hline \multirow[t]{3}{*}{5} & 30 & 4.68 & 4.76 & 0.210 & 0.8905 & 2.47 & 0.498 & 0.062 & 0.9927 \\
\hline & 60 & 28.84 & 2.80 & 0.357 & 0.9471 & 4.34 & 0.169 & 0.089 & 0.9934 \\
\hline & 90 & 93.32 & 2.14 & 0.467 & 0.8734 & 3.44 & 0.037 & 0.230 & 0.9905 \\
\hline
\end{tabular}

and intercept of plot $t / q_{\mathrm{t}} \mathrm{Vs} t$ (Fig. 11). The linear plot with correlation coefficient $\left(r^{2}\right)$ 0.997-0.998 (as shown in Table 1). It shows a good correlation to the $q_{\mathrm{e}}$ (Expt). From this results concluded that adsorption belongs to the second order kinetics model.

\section{Isotherm study}

Freundlich isotherm

The Freundlich isotherm is an equation used to describe heterogeneous systems and can be expressed in its logarithmic form as Eq.(3).The Freundlich adsorption isotherm equation is applied for a MG dye.

$\log q_{\mathrm{e}}=\log k_{f}+\left(\frac{1}{n}\right) \log C_{\mathrm{e}}$

where $q_{\mathrm{e}}$ is the amount of dye adsorbed $\left(\mathrm{mg} \mathrm{g}^{-1}\right)$ and $C \mathrm{e}$ is the equilibrium concentration of dye in solution (mg $\mathrm{l}^{-1}$ ). The $K_{\mathrm{f}}$ and $n$ are the constants involved in factors affecting adsorption process. The linear plot of $\log q_{\mathrm{e}}$ vs $\log C_{\mathrm{e}}$ shows Freundlich adsorption. In adsorption $K_{\mathrm{f}}$ value increases the quantity of dye adsorbed onto the surface of PANI-NiFe ${ }_{2} \mathrm{O}_{4}$ also increases (Fig. 12).The slope $1 / n$ ranging between 0 and 1 is the measure of adsorption extent or surface becomes heterogeneous as its value gets closer to zero. The values of $1 / n$ are between 0.210 and 0.467 for $30-90 \mathrm{mg} \mathrm{l}^{-1}$ dye conc. and adsorbent dose 5

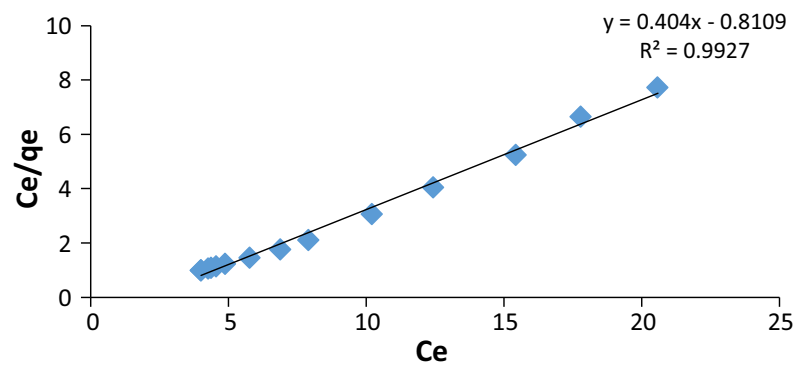

Fig. 13 Langmuir plot for adsorption of a MG dye by PANI$\mathrm{NiFe}_{2} \mathrm{O}_{4}$ gm $1^{-1}$. Its value is not much closer to one therefore its fails for chemisorption. The calculated $R^{2}, K_{\mathrm{f}}$ and $1 / n$ values are presented in Table 2.

Langmuir isotherm

It explains adsorption on homogeneous site. It has been successful for the explanation of monolayer adsorption. The linear form of Langmuir equation is given as:

$\frac{C_{\mathrm{e}}}{q_{\mathrm{e}}}=\frac{1}{Q_{0} b}+\frac{C_{\mathrm{e}}}{Q_{0}}$

where $C_{\mathrm{e}}$ is the equilibrium concentration $\left(\mathrm{mg} \mathrm{l}^{-1}\right), q_{\mathrm{e}}$ is the amount of dye adsorbed at equilibrium $\left(\mathrm{mg} \mathrm{g}^{-1}\right)$ and $Q_{\mathrm{o}}\left(\mathrm{mg} \mathrm{g}^{-1}\right)$ is the monolayer coverage capacity, $b$ is Langmuir isotherm constant $\left(\mathrm{lmg}^{-1}\right)$. The values of $Q_{\mathrm{o}}$ and $b$ are calculated from the slope and intercepts of the linear plots of $C_{\mathrm{e}} / q_{\mathrm{e}} \mathrm{Vs} C_{\mathrm{e}}$. It is shown in the (Fig. 13) calculated $Q_{\mathrm{o}}$ and $b$ values are presented in Table 2. The Langmuir adsorption predict the monolayer coverage of dye on PANI-NiFe ${ }_{2} \mathrm{O}_{4}$ nanocomposite. The dimensionless constant is called equilibrium parameter (RL).

$\mathrm{RL}=\frac{1}{1+b C_{\mathrm{i}}}$

where $b$ is the Langmuir constant, $\mathrm{Ci}$ is the initial dye concentration $\left(\mathrm{mg} \mathrm{l}^{-1}\right)$. When the rule $1 \geq \mathrm{RL} \geq 0$ is obeyed, Langmuir isotherm becomes favourable. The correlation coefficient of $r^{2}$ values for Langmuir isotherm is very closer to linearity value one is shown in Table 2. Langmuir isotherms are fit well to experimental data.

\section{Comparison of the results with traditional adsorbent}

In these adsorption experiments, good comparable results are obtained as compared to other removal traditional methods using low-cost adsorbent. In these experiments, adsorbent does not get recovered and reused. (God bole and Sawant 2006).In the present MG adsorbed by PANI$\mathrm{NiFe}_{2} \mathrm{O}_{4}$ adsorbent was dissolved in methanol, MG dye 
were easily desorbed by methanol solvent molecules. For reusability of PANI-NiFe ${ }_{2} \mathrm{O}_{4}$ were further separated it from the methanol solution using external magnet. As the PANI- $\mathrm{NiFe}_{2} \mathrm{O}_{4}$ was sufficiently magnetic therefore it was easily separated and reused, recycled repeatedly for number of times.

\section{Conclusions}

PANI-NiFe ${ }_{2} \mathrm{O}_{4}$ nanocomposite is successfully synthesised in situ through self polymerisation of monomer aniline. Adsorptive removal of $\mathrm{MG}$ dye using adsorbent dose (PANI-NiFe ${ }_{2} \mathrm{O}_{4}$ ) is successfully carried. The adsorption rate increased significantly by increasing amount of adsorption dose, while with an increasing dye concentration adsorption rate decreases. Neutral $\mathrm{pH}$ condition is found, which significantly affects the dye adsorption efficiency of MG dye is $95.2 \%$ and after elution the concentration of dye is $30 \mathrm{mg}^{-1}$. The present article confirms PANI-NiFe ${ }_{2} \mathrm{O}_{4}$ can be used adsorbent for the removal of a MG dye from aqueous solution. The amount of adsorbed dye is found from 2.3 to $4.09\left(\mathrm{mg} \mathrm{g}^{-1}\right)$ increased with an increase contact time and increase in initial dye concentration with an increasing adsorbent dose. The rate of adsorption is found to confirm the pseudo-second-order kinetics with good correlation with $R^{2}$ values. Langmuir isotherm model is found to fit with experimental.

Acknowledgments Authors are gratefully acknowledged to the Director UDCT, Jalgaon (M.S) for SEM, EDS \& XRD studies and are also thankful to Director of I.I.T. Madras for VSM studies. Authors are also thankful to the Principal of G.T.Patil College, Nandurbar for providing necessary laboratory facilities.

Open Access This article is distributed under the terms of the Creative Commons Attribution License which permits any use, distribution, and reproduction in any medium, provided the original author(s) and the source are credited.

\section{References}

Akl MA, Youssuf AM, Al-Awadhi MM (2013) Adsorption of acid dyes on to bentonite and surfactant modified bentonite. J Anal Bio anal Tech 4:4

Azhar SS, Liew AG, Subardy D, Hafiz KF, Hatim I (2005) Dye removal from aqueous solution by using adsorption on treated sugarcane Bagass. Am J Appl Sci 2:9

Culp SJ (2002) Mutagen city and carcinogenicity in relation to DNA adduct formation in rats fed leucomalachite green. Mutat Res 506-507:55-63

Ezgi A, Mufith B, Mustafa Y (2008) Removal of a calyx(4) arenebased polymer for water soluble carcinogenic direct azo dyes \& aromatic amines. J Hazard Mater 162:960-966

God bole PT, Sawant AD (2006) Removal of malachite green from aqueous solutions using immobilised saccharamyces cerevisiae. J Sci \& Ind Res 65:440-442

Hammed BH, Ahmed AA (2009) Batch adsorption of methylene blue from aqueous solution by garlic pee $\&$ agricultural west by material biomass. J Hazard Mater 164:870-875

Mahto TK, Chowdhuri AR, Sahu SK (2014) Polyaniline-functionalised magnetic nanoparticles for the removal of toxic dye from wastewater. J Appl Polym Sci 131:19

Patil MR, Shrivastava VS (2014) Photocatalytic degradation of carcinogenic methylene blue by using polyaniline-nickel ferrite Nano-composite. Pelagia Res Libr 5(2):8-17

Tavallali H, Daneshyar A (2012) Fast removal and recovery of congo red by modified iron oxide magnetic nanoparticles. Int $\mathrm{J}$ Chem Tech Res 4(3):1174-1177 